\title{
Effects of Students Perception and Motivation on Online Accounting Learning During the Covid-19 Pandemic: Empirical Evidence of Accounting Students in Indo Global Mandiri University
}

\author{
Eka Diana Sari ${ }^{1)}$, Lukita Tripermata ${ }^{2)}$, Muhammad Hamdan Sayadi ${ }^{3)}$ \\ 1), 2), 3), Universitas Indo Global Mandiri, Palembang, Indonesia \\ Email: ekadianasari15@gmail.com ${ }^{1)}$,lukita@uigm.ac.id ${ }^{2}$,hamdansayadi@uigm.ac.id ${ }^{3)}$
}

\begin{abstract}
This study aims to determine the effect of student perceptions and motivation on online accounting learning in the Covid-19 pandemic era. The data were obtained from observations and distributing questionnaires to 76 students majoring in the accounting study program at Universitas Indo Global Mandiri Palembang class of 2017-2020. The collected data were analyzed using the multiple linear regression analysis methods. Further statistical tests revealed a positive influence between perception and motivation respectively and simultaneously on online accounting learning in the era of the Covid-19 pandemic. Furthermore, the results show the coefficient of determination $\left(\mathrm{R}^{2}\right)$ obtained a value of 0.586 . This proves that students' perceptions and motivation affect online accounting learning by $58.6 \%$, the remaining is influenced by other variables not included in this study.
\end{abstract}

Keywords: perception, motivation, online accounting learning, covid-19 pandemic

\section{Introduction}

The development of appropriate learning models aims to create learning conditions so that students are enabled to learn actively and comfortably so that students can achieve optimal learning outcomes and learning achievements. Real learning comes from the active involvement of students with their lessons and not just listening to presentations from lecturers so that real learning is creating knowledge, not just absorbing information (Octavia, 2020: 13). Therefore, the stage of delivering material in the learning process is not only something done by the facilitator, namely the lecturer himself, but something that actively involves students in creating knowledge at every step.

The current learning method is no longer implemented face-to-face but has used online learning methods. This is because at the end of 2019 the world was shocked by the outbreak of the Corona Virus Disease (Covid-19). Indonesia as one of the countries affected by this outbreak, on March 2, 2020 the government announced that Covid-19 had spread in Indonesia. In an effort to prevent the spread of Covid-19, it is necessary to take measures such as social distancing. The Minister of Education and Culture of the Republic of Indonesia Number 4 of 2020 issued a circular regarding education in the Covid-19 emergency period containing the implementation of distance learning according to the conditions of each university (Jamil \& Aprilisanda, 2020: 38). The Indo Global Mandiri University (UIGM) Palembang has also implemented distance learning with an online system to participate in stopping the spread of the Covid-19 outbreak according to government recommendations.

Online learning is learning that uses a network with accessibility, connectivity, flexibility, and the ability to bring up various types of learning interactions (Sadikin \& Hamidah, 2020). The 
online learning method is a teaching and learning activity that was originally carried out on campus but is now carried out independently at home. Many students are not familiar with this online learning system, because this method is very dependent on the internet network. This learning service system is through application-based media that features text, images and slide recordings from presenters which are accessed via cellphones and laptops (Yungga \& Sunarsi, 2007). 2020: 55). The use of mobile technology makes a major contribution to educational institutions, including the achievement of distance learning goals.

In its implementation, it causes various positive and negative reactions. online accounting learning makes the lecture schedule more flexible and some think that online learning is not optimal considering accounting learning is still considered difficult because it requires high understanding, special skills, accuracy, thoroughness and caution to analyze accounting issues especially with the current online learning conditions. .

Several studies according to Istiyana and Fatmawati (2020) regarding the acceptance of students majoring in accounting for online learning during the covid-19 pandemic, that students majoring in accounting received online learning well. Students majoring in accounting that are sampled in this case are generation $\mathrm{Z}$ who are sensitive to technology. In Soraya, Suherman and Zawitri's research (2020) regarding the use of Moodle-based e-learning in increasing motivation and learning outcomes in introductory accounting 1, it was found that students were very happy and satisfied with participating in online learning so that students felt the benefits of Moodlebased e-learning and pre-school results. -test, post-test and mid-semester exam scores found that learning with an online system can increase motivation and learning outcomes are better when compared to full face-to-face learning. This study contributes to students majoring in accounting using e-learning based on Moodle as an alternative to distance learning. Adijaya and Santosa's research (2018) regarding student perceptions of online learning, found that students faced several obstacles in interacting, not only with other students but also with lecturers. The learning environment in online learning does not support them in the teaching and learning process.

Based on the existing phenomena and the existence of a research gap in similar research, the researchers are interested in conducting a study entitled "The Influence of Student Perception and Motivation on Online Accounting Learning in the Covid-19 Pandemic Era (Empirical Study on Accounting Students at Indo Global Mandiri University Palembang)". The formulation of the problem in this study are (1) Do students' perceptions and motivations affect online accounting learning at Indo Global Mandiri University students in Palembang? (2) Does student perception affect online accounting learning at Indo Global Mandiri University Palembang students? (3) Does student motivation affect online accounting learning at Indo Global Mandiri University Palembang students?

\section{Literature Review}

\subsection{Perception}

According to Zuhriyah (2020: 17) perception is a response that arises from an attraction to an object, which further reacts to decisions. One of the factors that influence a person's identity in responding to the presence of various aspects and symptoms around him from that perception. Perception is a process by which individuals choose to organize and interpret stimuli into a clear meaningful picture. In this study, perception as an independent variable consists of two instruments that will support the research material, namely: 


\section{Perception of Ease}

Perceived convenience is defined as the extent to which a person believes that using a technology will be free of effort. Perception of convenience gives an indication that a system is not designed to make it difficult for the user, but the user actually makes it easier for someone to get things done. In other words, someone who uses the system will work easier than someone who does not use the system or manually (Respati \& Setyowati, 2017). Based on this definition, it can be concluded in relation to research that the perception of ease with the online accounting learning system in the era of the covid-19 pandemic is expected to make students confident in their perception of the ease of carrying out accounting learning.

2. Perception of Usefulness

Perception of usefulness is defined as a level where a person believes that a certain object will be able to improve one's performance results (Respati \& Setyowati, 2017). Based on this definition, it can be concluded in relation to research that the perceived usefulness of the online accounting learning system in the era of the covid-19 pandemic is expected to benefit students in their implementation both in terms of learning outcomes.

\subsection{Motivation}

Motivation is a driving factor to achieve or achieve something desired. In the context of learning, motivation can be interpreted as a motivating factor for someone to be successful in learning. Motivation is a variety of dynamic factors and is influenced by a person's physical and psychological needs, experiences, and the environment (Reynolds et al, 2017: 4).

According to Lubis (2017: 118) motivation is an important concept for the behavior of accountants as well as a student studying accounting itself, because organizational effectiveness depends on the people who shape it as the student is expected to be formed. Accounting control systems require an understanding of how individuals can be motivated by accounting theory. Empirically, accounting theory plays an important role in ending the statement that motivation is a complete problem that cannot be solved by one theory.

In general, motivation is divided into two types which will be the instrument in this study, namely intrinsic motivation, students who are intrinsically motivated will involve themselves in learning to achieve their own academic and personal goals who always want to progress in learning, the desire for this is motivated by positive thinking. that all the lessons learned now will be useful for him both now and in the future. Furthermore, extrinsic motivation arises in a person because of an external urge, has extrinsic motivation to learn if students place their learning goals outside of what is being discussed, for example to achieve high scores, degrees, and honors.

\subsection{Hypothesis}

H1 : Students' perceptions and motivations are suspected to have a significant effect on online accounting learning because the better students' perceptions and motivations, the better the results obtained in online accounting learning in the covid-19 pandemic era.

H2 : Student perceptions are suspected to have a significant effect on online accounting learning, meaning that the better students' perceptions through the ease and usefulness indicators, the higher the possible level of influence on online accounting learning in the covid-19 pandemic era.

\section{Student motivation is suspected to have a significant effect on online accounting}


learning, meaning that the better the student's motivation by using intrinsic and extrinsic indicators, the higher the level of possible influence on online accounting learning in the covid-19 pandemic era.

\section{Research Method}

\subsection{Scope of Research}

This research was conducted at the Indo Global Mandiri University in Palembang. The location is at Jalan Jenderal Sudirman No. 629 Palembang, South Sumatra. The respondents in this study were students of the economics faculty majoring in accounting in 2017-2020.

\subsection{Data Collection Techniques}

In this study the authors used primary data and secondary data, namely writings and literature related to this research (Putri, 2020: 45). Primary data was obtained by conducting a direct survey to the object of research by distributing questionnaires through the google form link. The data taken is data related to research, namely statements of indicators of the perceived usefulness and convenience of the instrument, intrinsic motivation and extrinsic motivation, the content of the learning interface, feedback and assessment.

The data collection technique used a questionnaire via google form and was equipped with library research data. The measurement scale in this study uses an ordinal scale which is a measurement used to distinguish data, as well as containing an element of ranking, degree, or level through assessment and reaction to a particular question or statement.

\subsection{Population and Sample}

The target population in this study were students majoring in active accounting at Indo Global Mandiri University (UIGM) Palembang.

Table 1. Number of Accounting Students

\begin{tabular}{|c|c|c|}
\hline No & Batch & Number of Students \\
\hline 1 & 2017 & 83 \\
\hline 2 & 2018 & 84 \\
\hline 3 & 2019 & 62 \\
\hline 4 & 2020 & 83 \\
\hline \multicolumn{2}{|c|}{ Total } & 312 \\
\hline
\end{tabular}

Source: BAK UIGM Palembang

From this population, it can be determined the number of samples to be studied using simple random sampling, namely the selection of samples at random, the number of which is determined using the Slovin formula with an element of 10\% inaccuracy, so the sample obtained in this study is 76 accounting students from a total of 312 population. 


\subsection{Data Analysis Techniques}

This research is a quantitative research. Testing data processing and analysis in this study using SPSS 26 which consists of descriptive analysis, data quality test, classical assumption test and hypothesis testing.

\section{Findings and Discussions}

\subsection{Research Results}

This analysis aims to provide an overview or describe the data in the variables seen from the average (mean), minimum, maximum and standard deviation values.

Table 2. Descriptive Statistics

\begin{tabular}{|c|c|c|c|c|c|}
\hline Variable & N & $\begin{array}{c}\text { Minimu } \\
\mathbf{m}\end{array}$ & $\begin{array}{c}\text { Maximu } \\
\mathbf{m}\end{array}$ & $\begin{array}{c}\text { Mea } \\
\mathbf{n}\end{array}$ & Std. Deviation \\
\hline Student Perception (X1) & 7 & 14 & 40 & 26.05 & 5.801 \\
\hline Student Motivation (X2) & 7 & 17 & 40 & 28.99 & 4.084 \\
\hline Online Accounting Learning (Y) & 7 & 17 & 45 & 30.41 & 5.567 \\
\hline
\end{tabular}

Based on the table above, it shows that $\mathrm{N}$ or the amount of data for each valid variable is 76 , from the sample data for each variable, it is known that the mean value is greater than the standard deviation, thus identifying that the results are quite good. This is because the standard deviation is a reflection of very high deviations, so that the data distribution shows normal results.

\section{F Uji test}

In this study, the F test was used to simultaneously test the effect of the independent variables on the dependent variable. If the independent variable has a simultaneous influence on the dependent variable, this test is carried out by comparing the significant value of Fcount $>$ Ftable, it means that the regression model is correct, meaning that the effect is joint.

Table 3. F Test Results

\begin{tabular}{|l|l|r|r|r|r|r|}
\hline \multicolumn{7}{|c|}{ ANOVA $^{\mathrm{a}}$} \\
\hline \multirow{2}{*}{ Model } & $\begin{array}{c}\text { Sum of } \\
\text { Squares }\end{array}$ & Df & Mean Square & F & Sig. \\
\hline \multirow{2}{*}{1} & Regression & 1361.490 & 2 & 680.745 & 51.611 & $.000^{\mathrm{b}}$ \\
\cline { 2 - 8 } & Residual & 962.866 & 73 & 13.190 & & \\
\cline { 2 - 8 } & Total & 2324.355 & 75 & & & \\
\hline
\end{tabular}


a. Dependent Variable: Online Accounting Learning (Y)

b. Predictors: (Constant), Student Motivation (X2), Student Perception (X1)

Based on the results of the study in the table above, it can be seen that the Fcount value of 51.611 with the Ftable value is 3.12 so that Fcount $>$ Ftable or $51.611>3.12$ and a significant level of $0.000<0.05$ then $\mathrm{H} 0$ is rejected and $\mathrm{H} 3$ is accepted, it can be concluded that the Perception variable Students (X1) and Student Perceptions (X2) simultaneously have a significant effect on Online Accounting Learning in the Era of the Covid-19 Pandemic in Accounting Department Students, Indo Global Mandiri University, Palembang.

t- Test (Partial)

This test is carried out by looking at the significant column in each independent variable with a significant level of $<0.05$. The value of ttable $=\mathrm{t}(\alpha / 2 ; \mathrm{n}-\mathrm{k}-1=\mathrm{t}(0.05 / 2 ; 76-2-1)=(0.025: 73)$ $=1.99300$, tcount $>$ ttable then the hypothesis that reads is accepted.

Table 4. t-Test Results (Partial)

\begin{tabular}{|c|c|c|c|c|c|c|}
\hline \multicolumn{7}{|c|}{ Coefficients $^{\mathbf{a}}$} \\
\hline \multirow{2}{*}{\multicolumn{2}{|c|}{ Model }} & \multicolumn{2}{|c|}{$\begin{array}{l}\text { Unstandardized } \\
\text { Coefficients }\end{array}$} & \multirow{3}{*}{$\begin{array}{c}\begin{array}{c}\text { Standardized } \\
\text { Coefficients }\end{array} \\
\text { Beta }\end{array}$} & \multirow{3}{*}{$\begin{array}{l}\mathrm{t} \\
.784\end{array}$} & \multirow{3}{*}{$\begin{array}{l}\text { Sig. } \\
.436\end{array}$} \\
\hline & & B & Std. Error & & & \\
\hline \multirow[t]{3}{*}{1} & (Constant) & 2.381 & 3.036 & & & \\
\hline & Student Perception (X1) & .448 & .084 & .467 & 5.338 & .000 \\
\hline & Student Motivation (X2) & .564 & .119 & .414 & 4.732 & .000 \\
\hline
\end{tabular}

It can be seen from the results of tcount that the level of each independent variable of perception (X1) and motivation (X2) is 0.000 which with a significance level of $<0.05$, it means that each variable has a positive and significant effect. Furthermore, the perception variable tcount (X1) is $5.338>$ ttable 1.99300 so that the hypothesis which reads that there is an effect of student perceptions on online accounting learning is partially accepted. On the motivation variable (X2) tcount $4.732>$ ttable 1.99300 so that the hypothesis which reads that there is an influence of student motivation on online accounting learning is partially accepted.

\subsection{Discussion}

\section{Students' Perceptions and Motivations Together Affect Online Accounting Learning in the Era of the Covid-19 Pandemic.}

Judging from the Fcount value of 51.611 with Ftable value is 3.12 so that Fcount $>$ Ftable or $51.611>3.12$ and a significant level of $0.000<0.05$ then $\mathrm{H} 0$ is rejected and H1 is accepted, it can be concluded that the variable Student Perception (X1) and Student Perception (X2) simultaneously has a significant effect on Online Accounting Learning in the Era of the Covid- 
19 Pandemic in Accounting Department Students, Indo Global Mandiri University, Palembang.

Based on the results of the research, the hypothesis shows that there is a joint positive and significant influence between students' perceptions and motivations on online accounting learning. From the answers to the questionnaires filled in by the respondents, online accounting learning provides a more up-to-date and user-friendly learning method and the task testing method provided is fair and fair.

The results of this test are in accordance with the sound of attribution theory which explains and predicts the influence of an individual's behavior in dealing with certain situations in this study online accounting learning in the conditions of the covid-19 pandemic era in the midst of an outbreak that occurred. That the better the level of perception and motivation of students together in accepting online accounting learning, the higher the level of influence of understanding in online accounting learning in the conditions of the covid-19 pandemic outbreak.

The results of this first test are in line with the results of previous research tests, namely research conducted by Anwar, et al (2020) and Utami (2019), both studies support a positive and significant influence between student perceptions and motivations on online accounting learning.

\section{The Influence of Student Perceptions on Online Accounting Learning in the Covid-19 Pandemic Era}

To partially test the hypothesis, the t-test was used, namely to partially test the independent variables on the dependent variable. The student perception variable (X1) has a positive and significant effect on online accounting learning in the covid-19 pandemic era. This can be seen from the significant perception of students (X1) $0.000<0.05$. The value of ttable $=\mathrm{t}(\alpha / 2 ; \mathrm{nk}-1$ $=\mathrm{t}(0.05 / 2 ; 76-2-1)=(0.025: 73)=1.99300$. It means that the value of tcount is greater than ttable $(5.338>1,99300)$, then $\mathrm{H} 0$ is rejected and $\mathrm{H} 2$ is accepted, so the hypothesis which reads that there is an effect of student perceptions on online accounting learning is partially accepted.

Based on the results of the research, the hypothesis shows that there is a positive and significant influence between students' perceptions of online accounting learning. From the answers to the questionnaires filled in by the respondents, online accounting learning makes it easier for students to discuss questions with lecturers and other students, either through whatsapp groups or e-learning that has been provided by the forum. Online accounting learning makes student time schedules more flexible and useful for recognizing their own potential and abilities.

The results of this test are in accordance with the sound of attribution theory which explains and predicts the influence of an individual behavior where in this study is the perception of students in dealing with certain situations in online accounting learning in the era of the covid19 pandemic. That the better the student's perception of accepting online accounting learning, the higher the level of influence of understanding in online accounting learning in this covid19 pandemic condition.

The results of this second test are in line with the results of previous research tests which also support a positive and significant relationship between students' perceptions of online learning, namely the research conducted by Istiyana and Fatmawati (2020) and Zhafira, et al (2020). online well, where students majoring in accounting that are sampled are generation $\mathrm{Z}$ who are sensitive to technology and online learning is very popular among students. 


\section{The Influence of Student Motivation on Online Accounting Learning in the Covid-19 Pandemic Era}

To partially test the hypothesis, the t-test was used, namely to partially test the independent variables on the dependent variable. The student motivation variable (X2) has a positive and significant effect on online accounting learning in the era of the covid-19 pandemic. This can be seen from the significant student motivation (X2) $0.000<0.05$. The value of ttable $=\mathrm{t}(\alpha / 2$; $\mathrm{nk}-1=\mathrm{t}(0.05 / 2 ; 76-2-1)=(0.025: 73)=1.99300$. It means that the value of tcount is greater than ttable $(4.732>1,99300)$, then $\mathrm{H} 0$ is rejected and $\mathrm{H} 3$ is accepted, so the hypothesis that reads is that there is an influence on student perceptions of online accounting learning.

Based on the results of the research, the hypothesis shows that there is a positive and significant influence between student motivation on online accounting learning. From the answers to the questionnaires filled in by the respondents, online accounting learning encourages students to try to control their learning progress to be better at completing the given tasks with their own abilities in a timely manner according to the guidelines provided in online learning forums.

The results of this test are in accordance with the sound of attribution theory which explains and predicts the influence of an individual's behavior where in this study the motivation of students in dealing with certain situations in online accounting learning in the era of the covid19 pandemic. That the better the student's motivation in accepting online accounting learning, the higher the level of influence of understanding in online accounting learning in this covid19 pandemic condition.

The results of this third test are in line with the results of previous research tests which also support a positive and significant relationship between motivation and online learning, namely the research conducted by Suherman and Zawitri (2020) in which the results of his research that learning with an online system can increase motivation and learning outcomes for the better. when compared to full face-to-face learning. This research contributes to accounting students using e-learning as an alternative to distance learning. Research Soraya, et al (2020) that students are very happy and satisfied following online learning.

\section{References}

Adijaya, Nuryansyah., \& Santosa, Lestanto, Pudji (2018). Persepsi Mahasiswa dalam Pembelajaran Online. 105-110, Universitas Esa Unggul, Jakarta

Anwar, H., Amin, M., \& Anwar, S. A. (2020). Persepsi dan Minat Mahasiswa Jurusan Akuntansi Terhadap Mata Kuliah Akuntansi Syariah. E-JRA , Vol.09 No.02, 107-119.

Aslami, Nuri. (2020). Potensi E-Learning Melalui Sistem Kuliah Online Dalam Meningkatkan Mutu Pembelajaran Prodi Manajemen. Skripsi , 1-63, Universitas Islam Negeri Sumatera Utara Medan.

Istiyana, A. N., \& Fatmawati. (2020). Keberterimaan Mahasiswa Jurusan Akuntansi terhadap Pembela-jaran Daring pada Masa Pandemic Covid-19. AKUNSIKA : Jurnal Akuntansi dan Keuangan, Volume 1 Nomor 2.

Jamil, S. H., \& Aprilisanda, I. D. (2020). Pengaruh Pembelajaran Daring Terhadap Minat Belajar Mahasiswa pada Masa Pandemik Covid-19. BAJ (Behavioral Accounting Journal) , Vol. 3, No. 1. 
Kemendikbud. (2020, Agustus 7). Retrieved Oktober 15, 2020, from Kementerian Pendidikan dan Kebudayaan: https://www.kemdikbud.go.id/main/blog/2020/08/guru-dimintaprioritaskan-materi-esensial-di-masa-pandemi-covid19

Lubis, A. I. (2017). Akuntansi Keperilakuan (3nd Edition ed.). Jakarta: Salemba Empat.

Octavia, S. A. (2020). Model-model Pembelajaran. (A. D. Nabila, A. H. Zein, \& A. Y. Wati, Eds.) Yogyakarta: Deepublish.

Putri, Andini. Utari. (2020). Analisis Faktor-faktor yang Mempengaruhi Produktivitas Tenaga Kerja (Studi Kasus pada Usaha Roti Donat Eve Bakery di Palembang). Jurnal Ilmiah Ekonomi Masa Kini, Vol.11 No.01 Hal.40-48

Reynolds, K. M., Roberts, L. M., \& Hauck, J. (2017). Exploring motivation: Integrating the ARCS modelwith instruction. 1-31.

Respati, Agustini, Dyah., \& Setyowati, Elisabeth, Oktaviana Tri. (2017). Persepsi Kemudahan Penggunaan, persepsi manfaat, computer self efficacy, Dan Kepuasan Pengguna Sistem Informasi Akuntansi. Jurnal Riset Akuntansi dan Keuangan.

Sadikin, Ali., \& Hamidah, Afreni. (2020). Pembelajaran Daring di Tengah Wabah Covid-19. Vol.6, No 02, 215-224.

Saputra, R., \& Kustina, K. T. (2019). Minat Mahasiswa Akuntansi Untuk Mengikuti Pendidikan Profesi Penilai Ditinjau Dari Motivasi Sosial, Motivasi Karir dan Motivasi Karir. Jurnal Ilmiah Akuntansi \& Bisnis, Volume 4, No, 73-80.

Shalikhah, N. D., Primadewi, A., \& Iman, M. S. (2017). Media Pembelajaran Interaktif Lectora Inpire Sebagai Inovasi Pembelajaran. WARTA LPM , Vol. 20, No. 1, 9-16.

Soraya, Suherma, L., \& Zawitri, S. (2020, Juni). Pemanfaatan E-Learning Berbasis Moodle Dalam Meningkatkan Motivasi dan Hasil Belajar Pengantar Akuntansi 1. Jurnal Eksos, 72-83.

Utami, D. P. (2020). Analisis Pengaruh Kompetensi Mahasiswa, Gaya Belajar Mahasiswa, dan Motivasi Belajar Terhadap Prestasi Belajar Akuntansi Keuangan Pada Mahasiswa STIE Widya Wiwaha Yogyakarta Prpgram Studi Akuntansi. Skripsi , 1-67.

Yuangga, K. D., \& Sunarsi, D. (2020). Pengembangan Media dan Strategi Pembelajaran Untuk Mengatasi Permasalahan Pembelajaran Jarak Jauh di Pandemi Covid-19. Vol. 4 No. 3, 51-58.

Zhafira, N. H., Ertika, Y., \& Chairiyaton. (2020). Persepsi Mahasiswa Terhadap Perkuliahan Daring Sebagai Sarana Pembelajaran Selama Masa Karantina Covid-19. Jurnal Bisnis dan Kajian Strategi Manajemen, Volume 4 Nomor 1, 37-45.

Zuhriyah, F. (2020). Pengaruh Persepsi, Motivasi dan Sikap Konsumen Terhadap Keputusan Pembelian Kuota Smartfren. Skripsi , 13-45. 